Before long a large mud lodge had been constructed.

One Sunday afternoon we hiked along the shore of the creek, which is covered with a dense growth of poplar. We were quite amazed at the ingenuity of the beaver's work. White poplars were felled always leaning toward the water. The branches were severed off as neatly as with a saw. In one case a falling tree had caught in a thicket of willows, leaving it angled about fifteen feet above the ground. However, the industrious little "amik", as the Indians called them, had still rid it of its branches. We also noticed that a wide swath had been cleared through the rushes as a canal through which to float their "timber". Now that the ice is frozen we have the opportunity to observe the lodge closely, and what a wonderful piece of engineering it is! The way in which the sticks, mud, rushes and other muskeg material are constructed would put many a carpenter to shame. With the arrival of spring we shall watch with interest our beaver colony, for truly some of Mother Nature's finest sons are these animal engineers.

\section{A Wren Finds a Home}

By Lynne Maddaford, Saltcoats, Sask. Age 12, Grade 7

One morning Mother washed and hung my brother's overalls on the clothes line. That evening she went to the clothes line and found about half a wren's nest in the leg of the overalls We watched the next day and found that the wrens were putting the twigs in the top of the overalls and they were falling out of the bottom. I went out and tied a string around the bottom of the pant leg.

The wrens built their nest and laid their eggs. There were about seven or eight eggs in the nest. Mother washed the next week and Mr. Wren put twigs in all the overalls hung on the line. He sometimes sat on the line and sang while Mrs. Wren sat on the eggs.

The grass had grown long so the men had cut it with the horses. The line had to be taken down so the wrens and the pants were moved to the wind-charger tower where they raised their young ones.

\section{Ducks in Winter}

By Margaret Bawden, Marieval, Grayson, Sask.

My parents have lived within a few miles of here for over sixty years. Never before have they known ducks to stay here on the Qu'Appelle River. Since the P.F.R.A. dam has been built at Crooked Lake, the river has never frozen right by it.

This was a mild winter and so much water ran out of the lake that the river was open for about two miles down. On February 28th there were about five hundred ducks, three Mud Hens and two Kingfishers still here. It was common to hear the ducks quacking, but although we were told they sometimes fly down the valley to the open water at Round Lake dam, we never saw them flying over the lake.

One of the men here fed them with barley. He cleaned the snow away by the river and kept the grain there for the ducks to eat. After the ducks found it they kept coming back to the place again and again.

When my parents come out here first there were a few lynx around, but none had been seen for over forty-five years. Then on February $23 \mathrm{rd}$, two lynx walked past my sister's home and then across the Cotham school grounds. Doris phoned the teacher and she and the children had a good look at them. Some men went after the animals but although they saw them they never got close enough to shoot. Three days later there were fresh tracks around and again the men went out. They killed one outright, and the other, wounded, climbed a tree and died up there. They had to chop down the tree to get it.

(Editor's note: Isn't it unfortunate that a camera had not been used instead of a gun?)

\section{Albino Pheasant}

By Mrs. Creighton Smith, East Poplar, Sask.

Has anyone ever seen a pure white hen pheasant? I imagine there could be an albino among pheasants. $\mathrm{Mr}$. Wilk Keen, the Sask. Pool Elevator agent at Hart is sure that he saw one in that district within the last two weeks, but is afraid no one will believe him. 